\title{
AN ANALYSIS OF THE FATE OF PREMATURE BABIES IN WARWICKSHIRE FOR 1942 AND 1943
}

\author{
BY
}

\author{
C. FRASER BROCKINGTON, M.D., D.P.H. \\ County Medical Officer of Health
}

The attached tables show the fate of premature babies in the administrative County of Warwick during 1942 and 1943 (total births 7948 and 8650). The births are arranged in half-pound weight groups from $1-5 \frac{1}{2} \mathrm{lb}$.; babies over $5 \frac{1}{2} \mathrm{lb}$. in weight have been excluded in order to avoid the risk of including any babies in which the date of conception is in doubt. There is clearly some doubt as to what degree of inaccuracy such an arbitrary ceiling produces: that a few definitely premature infants have been excluded is certain, but the numbers are not large and the degree of prematurity is likely to be slight. Babies delivered by domiciliary midwives and some in nursing and maternity homes (approximately one-third of the total) were weighed on a spring balance. A number of spring balances in use by the midwives on the district have been examined for accuracy by the Weights and Measures Inspectors with the following results:-

$\left.\begin{array}{lrrr}\text { Correct } & \ldots & \ldots & 34 \\ \text { Error 2 oz. and under } & \ldots & 10 \\ \text { Error 2-4 oz. } & \ldots & \ldots & 24 \\ \text { Error 4-8 oz. } & \ldots & \ldots & 8 \\ \text { Error 8-16 oz. } & \ldots & \ldots & 2 \\ \text { Error over 1 lb. } & \ldots & \ldots & 1\end{array}\right\} \begin{gathered}\text { For weights up } \\ \text { to } 11 \mathrm{lb} .\end{gathered}$

On the whole, although the spring balance canno1 be accepted as an ideal method of weighing, there does not seem to be any reason to suppose that a midwife who is used to it will not obtain reasonably accurate measurements. As 68 out of 79 balances had an error of $4 \mathrm{oz}$. or under the possible error introduced by the use of the spring balance is not considered to be material. A small number of babies may have found their way into groups either one above or one below their true weight, but this would not appear to invalidate the figures.

\section{Comments}

Rate of prematurity. The rate of prematurity in the two years is 3.0 and 3.6 . This compares with rates recorded at the National Maternity Hospital, Dublin, of 3.0 (1940), 3.2 (1941), and 4.6 (1942).*

Relationship of survival to weight. (a) There is a close relationship between survival and weight in both years with a slightly better survival rate throughout for the year 1943. The coefficients of correlation for weight to survival were 0.97 (1942), 0.97 (1943). (These coefficients are 2.57 times the

PREMATURE BIRTHS IN WARWICKSHIRE, $\overline{1942}$

$\begin{array}{llllllll}\text { Total births } & \ldots & 7948 & \text { No. premature } & \ldots & 237 & \text { Percentage premature } & \ldots\end{array}$

\begin{tabular}{|c|c|c|c|c|c|c|c|c|c|c|c|c|c|c|c|}
\hline \multirow{3}{*}{\multicolumn{2}{|c|}{$\begin{array}{c}\text { Weight } \\
\text { group lb. }\end{array}$}} & & \multicolumn{2}{|c|}{$\begin{array}{l}\text { No. of prema- } \\
\text { ture births }\end{array}$} & \multicolumn{9}{|c|}{ No. dying (days of survival) } & \multirow{3}{*}{$\begin{array}{c}\text { No. sur- } \\
\text { viving }\end{array}$} & \multirow{3}{*}{$\begin{array}{l}\text { Per- } \\
\text { centage } \\
\text { surviva }\end{array}$} \\
\hline & & & \multirow{2}{*}{$\begin{array}{l}\text { Born } \\
\text { alive }\end{array}$} & \multirow{2}{*}{$\begin{array}{l}\text { Born } \\
\text { dead }\end{array}$} & \multicolumn{7}{|c|}{ First week } & \multirow{2}{*}{$\begin{array}{l}\text { Second } \\
\text { week }\end{array}$} & \multirow{2}{*}{ Over } & & \\
\hline & & & & & 1 & 2 & 3 & 4 & 5 & 6 & 7 & & & & \\
\hline $\begin{array}{l}5-5 \frac{1}{2} \ldots \\
4 \frac{1}{2}-5 . \\
4-4 \frac{1}{2} \ldots \\
3 \frac{1}{2}-4 . \\
3-3 \frac{1}{2} \ldots \\
2 \frac{1}{2}-3 \ldots \\
2-2 \frac{1}{2} \ldots \\
1 \frac{1}{2}-2 \ldots \\
1-1 \frac{1}{2} \ldots\end{array}$ & $\begin{array}{l}\ldots \\
\cdots \\
\cdots \\
\cdots \\
\cdots \\
\cdots \\
\cdots\end{array}$ & $\begin{array}{l}\ldots \\
\ldots \\
\ldots \\
\ldots \\
\ldots \\
\ldots \\
\ldots \\
\ldots\end{array}$ & $\begin{array}{r}84 \\
33 \\
42 \\
27 \\
24 \\
10 \\
12 \\
4 \\
1\end{array}$ & $\begin{array}{r}7 \\
4 \\
10 \\
3 \\
3 \\
2 \\
5 \\
0 \\
0\end{array}$ & $\begin{array}{l}1 \\
1 \\
4 \\
4 \\
3 \\
4 \\
5 \\
3 \\
0\end{array}$ & $\begin{array}{l}1 \\
1 \\
2 \\
1 \\
0 \\
0 \\
4 \\
1 \\
1\end{array}$ & $\begin{array}{l}0 \\
2 \\
1 \\
0 \\
0 \\
2 \\
2 \\
0 \\
0\end{array}$ & $\begin{array}{l}2 \\
1 \\
0 \\
1 \\
2 \\
0 \\
0 \\
0 \\
0\end{array}$ & $\begin{array}{l}0 \\
0 \\
0 \\
1 \\
2 \\
1 \\
0 \\
0 \\
0\end{array}$ & $\begin{array}{l}0 \\
1 \\
0 \\
0 \\
0 \\
0 \\
0 \\
0 \\
0\end{array}$ & $\begin{array}{l}2 \\
0 \\
1 \\
1 \\
1 \\
0 \\
0 \\
0 \\
0\end{array}$ & $\begin{array}{l}3 \\
0 \\
1 \\
1 \\
1 \\
0 \\
0 \\
0 \\
0\end{array}$ & $\begin{array}{l}0 \\
0 \\
0 \\
2 \\
0 \\
0 \\
0 \\
0 \\
0\end{array}$ & $\begin{array}{r}75 \\
27 \\
33 \\
16 \\
15 \\
3 \\
1 \\
0 \\
0\end{array}$ & $\begin{array}{r}89 \cdot 3 \\
81 \cdot 9 \\
78 \cdot 6 \\
59 \cdot 3 \\
62 \cdot 6 \\
30 \cdot 0 \\
8 \cdot 3 \\
00 \cdot 0 \\
00 \cdot 0\end{array}$ \\
\hline \multirow{2}{*}{\multicolumn{2}{|c|}{ Total .. }} & . & 237 & 34 & 25 & 11 & 7 & 6 & 4 & 1 & 5 & 6 & 2 & \multirow[t]{2}{*}{170} & \multirow[t]{2}{*}{$71 \cdot 8$} \\
\hline & & & & & \multicolumn{9}{|c|}{67} & & \\
\hline
\end{tabular}




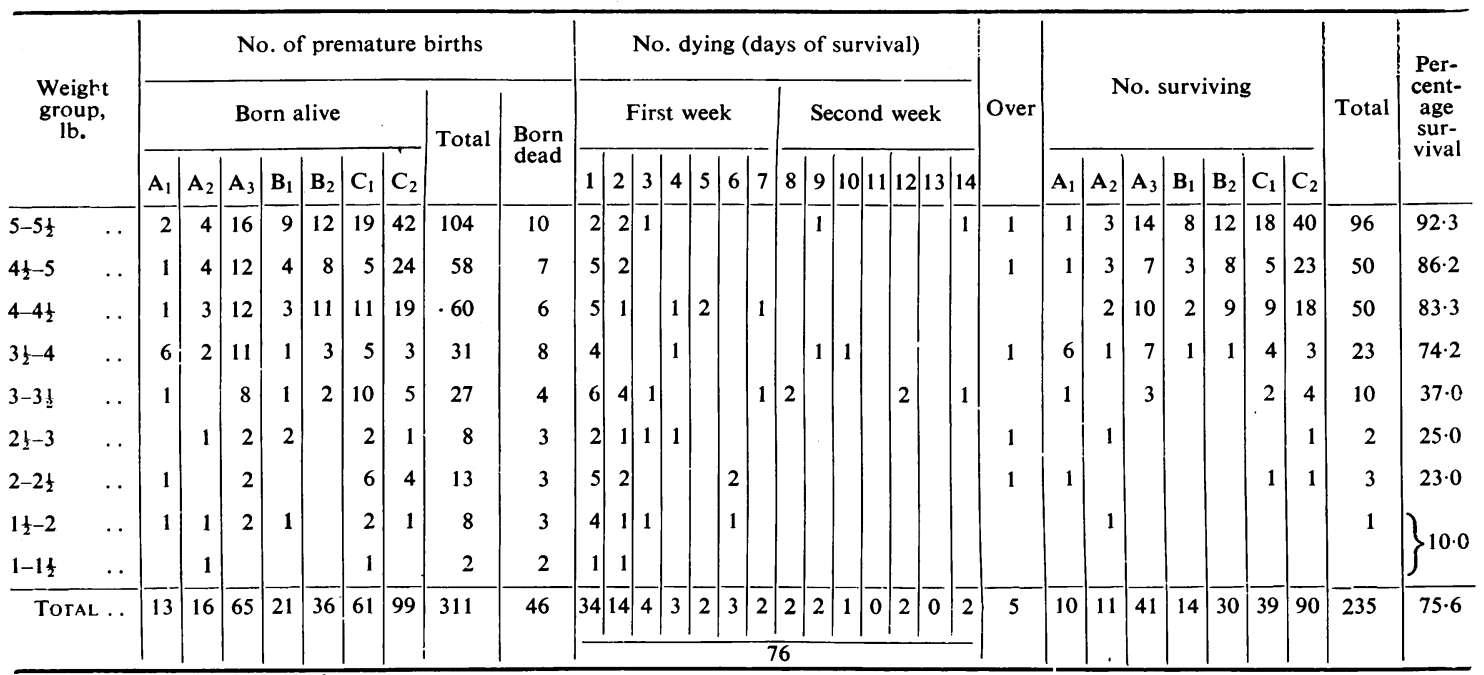

$A_{1}$ Attended by an independent midwife.

$B_{1}$ Born in a nursing home.

$A_{2}$ Attended by a county council midwife. B Born in a maternity home.

$\mathrm{C}_{1}$ Born in a municipal hospital.

$\mathbf{A}_{3}$ Attended by a district nursing association midwife.

$\mathrm{C}_{2}$ Born in a voluntary hospital.

standard error of 0.378 and can be regarded as significant.)

Of the babies weighing $5-5 \frac{1}{2} \mathrm{lb}$., $89 \cdot 3$ per cent. and 92.3 per cent. respectively survived; $4 \frac{1}{2}-5 \mathrm{lb}$. in weight, 81.9 and 86.2 per cent. respectively; 4-41 lb., 78.6 per cent. and 83.3 per cent. respectively; for $3 \frac{1}{2}-4 \mathrm{lb}$., $59 \cdot 3$ per cent. and 74.2 per cent. respectively; $3-3 \frac{1}{2} \mathrm{lb}$., 62.6 per cent. and 37.0 per cent. respectively; $2 \frac{1}{2}-3 \mathrm{lb}$., 30 per cent. and 25 per cent. respectively; $2-2 \frac{1}{2} \mathrm{lb}$., $8 \cdot 3$ per cent. and 23 per cent. respectively; of the two groups $1 \frac{1}{2}-2 \mathrm{lb}$. and $1-1 \frac{1}{2} \mathrm{lb}$., 0 per cent. and 10 per cent. respectively, the total survival rate being 71.8 per cent. and 75.6 per cent. respectively.

(b) Survival rates in both years remain fairly high down to the weight of $3 \frac{1}{2} \mathrm{lb}$. (74 per cent. 1943, 59 per cent. 1942), and in 1942 down to a weight of $3 \mathrm{lb}$. (62 per cent.). After this there is a sharp drop; thus the survival of the $2 \frac{1}{2}-3 \mathrm{lb}$. group in contrast was 25 per cent., 1943; 30 per cent., 1942. Below $2 \mathrm{lb}$., in both years together one baby out of a total of 15 survived. This baby weighed $1 \mathrm{lb}$. 14 oz., delivered on the Stratford-on-Avon district by a County Council midwife who, in response to an enquiry as to how it was kept alive, replied:-

' I got baby wrapped in cotton wool and olive oil. I gave it one teaspoonful sweetened condensed milk every hour for a week and gradually increased feeds until two-hourly feeds of humanized dried milk, and now he is on 3-hourly feeds and is $5 \frac{1}{2} \mathrm{lb}$. when I heard last.'

Length of survival of those dying. Some interest attaches to the length of survival of those premature infants dying particularly in view of the supposition that early deaths (say, within 48 hours) occur mainly in infants that are non-viable. The following is an analysis from this angle:-

Died within 48 hours:

54 per cent. (36 out of 67) in 1942.

63 per cent. (48 out of 76) in 1943.

Died in the first week:

88 per cent. and 80 per cent. respectively.

Of babies over $3 \frac{1}{2} \mathrm{lb}$. in 1943, 23 out of 36 dying, i.e., 64 per cent., and those under $3 \frac{1}{2}$ lb., 27 out of 58 dying, i.e., 46 per cent., died in the first 48 hours. In view of the high correlation between birth weight and chance of survival the fact that the percentage dying within 48 hours is higher in the higher weight groups supports the idea that babies dying early may be 'non-viable.'

Relationship of survival to midwifery services. The survival rate of babies born in an institution, i.e., hospital, nursing home, m. ternity home, was 72.6 per cent. and 80.0 per cent. for 1942 and 1943 respectively; a fraction better in each case than the overall rate. In 1943 a closer analysis according to midwifery circumstances showed the survival rates to be as follows:-
A. Domiciliary Midwives

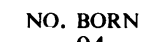
B. Nursing and Maternity Homes

\begin{tabular}{ccc} 
& \multicolumn{2}{c}{ NO. BORN } \\
$\ldots$ & $\ldots$ & 94 \\
mes & $\ldots$ & 57 \\
& & \\
$\ldots$ & $\ldots$ & 61 \\
$\ldots$ & $\ldots$ & 99
\end{tabular}
C. Municipal Hospital
D. Voluntary Hospital
NO. SURVIVING
62
PER CENT.
44
66
77
39
64
(Independent 77; C.C. 69;
D.N.A. 63.)
(Nursing Home 67;
Maternity Home 83.)

Differences: $\mathrm{D}-\mathrm{A}=25 \pm 5 \cdot 9$

$\mathrm{D}-\mathrm{B}=14 \pm 5 \cdot 8$

D-C $=27 \pm 7.0$ 
The voluntary hospital is shown to have a significantly higher rate of survival than the other three. The cause of this must remain in the absence of further evidence a matter of conjecture. Before it can be certain that the difference is due to a higher standard of nursing care the many other factors which enter into the problem of survival would have to be examined. On the whole, however, it is improbable that any of these factors would weigh in favour of the voluntary hospitals; for example, parity and the age of the mother, which are known to be related to infant mortality, might be expected to be of similar proportions in each group; again, illegitimacy might be more unfavourable to a premature baby born outside the hospital, but the numbers (not more than 5 per cent. of the total) are too small to have made much difference; on the other hand many abnormalities, such as toxaemias, inductions, caesareans, attempted abortions, and the like, which might affect survival adversely, would probably occur more frequently in hospitals; the chance of infection to which the premature infant is notoriously susceptible would also be greater in hospitals, the meeting place of many pathogenic organisms, and to achieve a high rate of survival the voluntary hospital must ipso facto overcome this disadvantage, presumably by care in the use of masks, strict isolation, the minimum of handling, and skilled nursing. A further examination of these particular points in the next year's series should prove of interest. 